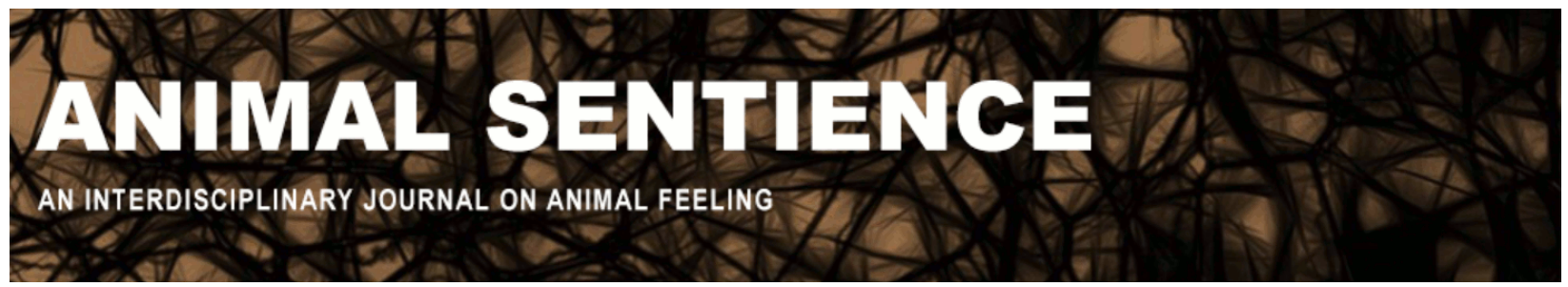

Calvo, Paco (2018) Caterpillar/basil-plant tandems. Animal Sentience 11(16) DOI: $10.51291 / 2377-7478.1298$

Date of submission: 2018-01-16

Date of acceptance: 2018-01-21

(c) (i)

This article has appeared in the journal Animal

Sentience, a peer-reviewed journal on animal

cognition and feeling. It has been made open access,

free for all, by WellBeing International and deposited

in the WBI Studies Repository. For more information,

please contact

wbisr-info@wellbeingintl.org.

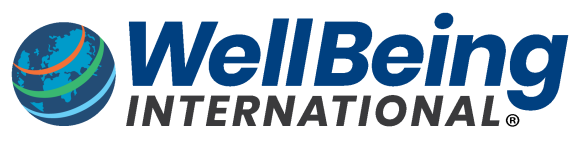

SOLUTIONS FOR PEOPLE, ANIMALS AND ENVIRONMENT 


\title{
Caterpillar/basil-plant tandems
}

\author{
Commentary on Reber on Origins of Mind
}

\author{
Paco Calvo \\ Minimal Intelligence Lab, Department of Philosophy \\ University of Murcia, Spain
}

\begin{abstract}
According to Reber (2016), subjectivity springs from primitive life itself. Granting his non-neurocentric stance, I shall try to show that his framework falls prey to zoocentric preconceptions that divest certain non-animal life-forms of mentality. There is no reason to exclude the possibility that plants have evolved different structures that underlie their own subjective experiences, all according to Reber's model. It is the degree of phenotypic flexibility and integration that we observe in the behavioral repertoire of plants that may end up supporting their capacity for subjective experience. This remains an open empirical question.
\end{abstract}

\begin{abstract}
Paco Calvo, Professor of Philosophy of Science, Minimal Intelligence Lab, University of Murcia, does research on the philosophy of plant neurobiology, ecological psychology and embodied cognitive science. He is currently writing a book on Plant Cognition. www.um.es/web/minimal-intelligence-lab
\end{abstract}

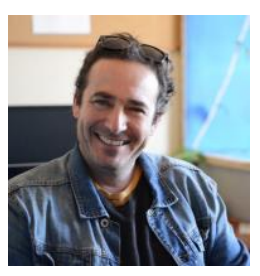

According to Reber's (2016) Cellular Basis of Consciousness (CBC) hypothesis, the origins of subjectivity are not to be found in patterns of neural activity; rather, mentality springs from (ancestral) life itself. This allows us to dissolve the category error that identifies subjectivity with human consciousness. The mental arises in any life-form where there is felt experience, however primitive, as Reber puts it in his target article: "All organisms that experience have minds, all have consciousness."

Granting that non-human experience is mental all the way down, evolutionary biology and not, say, computational neuroscience - proves to be a successful test-bed for tracing the origins of mind. But is experience truly mental all the way down? In my view, it is: in Reber's, apparently not. Doing away with neurocentrism still leaves zoocentric biases. The species continuum that Reber advocates is at heart an animal species continuum. He thus corrects one category error whilst committing another that rests on the following axiom (Reber 2016):

Mind and consciousness are not unique features of human brains. They are grounded in inherent features present in simpler forms in virtually every species. Any organism with flexible cell walls, a sensitivity to its surrounds and the capacity for locomotion will possess the biological foundations of mind and consciousness.

This apparently innocuous axiom is anything but self-evidently true. It implies that sentience is, first and foremost, animal sentience; it links mentality to having flexible cell walls and thereby 
excludes members of the Plantae and Fungi kingdoms from having mentality a priori, no matter how minimal. In a footnote, Reber elaborates the reasons for his veto: "I am excluding plants and fungi on the grounds that they have rigid cell walls composed of cellulose, hemicellulose and pectin (plants) or chitin (fungi), and lack the capacity for endogenous locomotion."

Plant cells, unlike animal cells, do indeed have rigid walls. ${ }^{1}$ They need rigidity to support themselves, to grow upright. But our perception is biased towards unconstrained animal movement. This prejudice misses behavioral patterns other than the movement of whole organisms visible to the naked eye. Put bluntly, rigidity makes us see plants as not behaving. But this only shows our incapacity to appreciate other forms of movement. Plants behave, although not in the way animals do. In animals, movement takes the form of displacement. Plant movement is not a form of locomotion. It goes by the name of "phenotypic plasticity," and has to do with changes in the observable characteristics of plants, in their morphology and physiology: growth, for example. A young tree made up of rigid cells reaches the canopy (and light) by growing taller, and not courtesy of free vegetal movement.

The mistake most of us make that perpetuates zoocentric biases becomes evident if we pay attention to the intuition that first led Reber to underline the cellular basis of mentality. As Reber (2016) recounts it:

This [intellectual voyage] began when I engaged with a small, green caterpillar munching on one of my basil plants.... Yet its behavior didn't seem all that mechanical. It wasn't much of a stretch to view it as engaging in something akin to a choice process - determining where to chew next, how large a piece to tear out, assessing whether it is safe to eat now or better to check for predators. I looked at the other leaves, each clipped in much the same fashion as one might expect, but each also noticeably different, as though novel decisions had been made as the caterpillar worked its way from leaf to leaf. I couldn't shake the feeling that not only did my caterpillar have a mind, but it had consciousness and that both of these phenomenal states were essential elements of its being. And I began to worry about the anthropomorphic fallacy.

If Reber found the anthropomorphic fallacy worrisome, why put the emphasis exclusively on the green caterpillar? How about the basil plant? Isn't it another kind of organic form that merits our attention? How about predator-prey tandems in co-evolution (Grüter et al. 2018)? Interestingly enough, the actors that give rise to the tandem may be treated on par, or not, discretionarily. In a plant- $X$ tandem, where $X$ is, say a predator or a pollinator, the plant is invariably treated as the "environment" for X. We don't even talk about the niche of a plant that, in a sense, supports her living.

Consider the caterpillar-basil tandem. The larva is seen as requiring a specific type of environment to do her harvesting. The basil provides this environment for the caterpillar. End of story, the roles never reverse; larvae are never reported as the environment for plants. However, we know that the munching of caterpillars results in specific vibrational patterns that plants are able to distinguish from the vibrations due to, say, wind. Such vibrations trigger chemical defense mechanisms in plants (Appel 2014). Plants can communicate aerially (via released volatile organic

\footnotetext{
${ }^{1}$ I focus on plants in the remainder of this commentary for the sake of concreteness, although, if sound, similar conclusions would hold for fungi.
} 
compounds - VOCs - Dicke et al. 2003; Baldwin et al. 2006). ${ }^{2}$ Some plants can even tell caterpillars apart from the particular fingerprint of their saliva (Acevedo et al. 2015). One way or another, it is clear that the spotlight cannot be put on either member of the plant-herbivore system in isolation.

As Reber (2016) bases his CBC upon evolutionary considerations, it may be a good time to bring Charles Darwin to the fore. Darwin was able to apply the same power of observation, but free of zoocentric prejudices.

Darwin devoted the last book he wrote, before his death in 1882, to earthworms - The Formation of Vegetable Mould, through the Action of Worms with Observations on Their Habits (1881). He took the intelligence of worms quite literally (Calvo, book ms.), setting himself the task of unveiling "how far the worms acted consciously and how much mental power they displayed." Earthworms help themselves to leaves and other organic leftovers, which they use to plug their burrows. Nothing special thus far; the plugging may be accounted for by resorting to instinct. If you are a worm, you plug your burrow, and plug it, and plug it. However, when you pay close attention to their habits, to how earthworms actually draw leaves or leftovers, the whole plot thickens. Earthworms can make subtle differentiations between their shapes, and decide, en route, how best to drag them. In Darwin's words, this couldn't but entail "some degree of intelligence."

Reber may have appreciated in caterpillars what Darwin spotted in earthworms. But to Darwin, botany was not subordinate to zoology: no golden connection between locomotion and mind. The connection was masterfully exemplified (in terms of what we would today call "phenotypic plasticity") in The Movements and Habits of Climbing Plants (1875), and most notably in The Power of Movement in Plants (1880), a gem Darwin wrote with his son Francis. Reber is nevertheless not alone in turning a blind eye to plants. In his hot-off-the-press book From Bacteria to Bach and Back (2017), Dennett writes:

Plants and other sessile organisms organize the cells that compose them into larger armies of slaves with particular tasks to perform, feeding and protecting them in return for their services as monitors, expediters, growth controllers, and so forth, without needing to invest in the sort of distal perception systems that permit an organism to be mobile without bumping into all the wrong things.

Recent research in plant science has called into question such a "couch potato" understanding of plant life (Baluška 2016; Calvo \& Keijzer 2011; Calvo \& Baluška 2015; Trewavas 2017). Plant behavior is in fact markedly anticipatory, goal-directed, reversible and soft-wired. Plants make decisions and solve complex problems. Roots can map the local terrain, growing away from

\footnotetext{
${ }^{2}$ Research on willow trees carried out in the early 1980s by David Rhoades provides the classic illustration. Rhoades (1985) noticed that when caterpillars were laid on willow trees in the vicinity of infested specimens, the larvae would not grow as much as those laid on willows surrounded by healthy fellow trees. The caterpillars would lose their appetite. As it turned out, some leaves contained certain chemicals, such as phenolic and tannic, that were unpleasant to the taste of caterpillars. Today we know that attacked trees pass along airborne warning signals, dictating the appropriate dosage, to their healthy neighbors. Such forms of communication allow plants to anticipate and defend themselves even before having been attacked. The details of all this have become a trending topic under the banner "talking tress," and have been reported ad nauseam, and so I will spare the reader the details.
} 
barriers or other targets before establishing contact with them (Falik et al. 2005). Roots and shoots can anticipate the future and compete for resources (Novoplansky 2016; Shemesh et al. 2010), growing differentially depending upon the future acquisition of minerals and water. Some plants can anticipate future shade, initiating phenotypic changes in response to red:far-red (R:FR) ratio light cues pro-actively (Franklin 2008).

Flexible and anticipatory behavior requires coordination across the root and shoot systems to achieve the plants' overall goals. This calls for the integration of information signaling (Trewavas 2014). Plants (and basil is no exception) are able to integrate a vast panoply of parameters - not just nutrient patches and micro-organisms in the soil, but of course humidity, light, gravity, temperature, and many others (Hodge 2009; Baluška \& Mancuso 2013). Plant proprioception has likewise been reported (Bastien et al. 2013; Dumais 2013). One way or another, what seems to be crucial in bridging the gap between mind and movement is that organic systems, regardless of their form, are able to organize their behavior non-reactively. One way to do so is by exploiting an integrated model of the environment, whereby the agent acts as a globally organized, coherent unit, and not as a collection of individual stimulus-response relations (Calvo, Baluška \& Sims 2016; Calvo \& Friston 2017). ${ }^{3}$ Bearing this in mind, if the goal-directed behavior of a green caterpillar can be considered to be the end result of the internal modeling of its local environment, the same can be said of the basil plant.

Given the theoretical framework of Reber's (2016) CBC, there is no empirical or theoretical reason to exclude the possibility that plants have evolved different structures that underlie their own subjective experiences (Calvo 2017). We can trace consciousness phylogenetically to the Cambrian period (Barron \& Klein 2016; Klein \& Barron 2016), with the proviso that the animal phylogenetic tree was not the one and only tree. As the fossil record shows, the Cambrian explosion in the evolution of land animals had a parallel in the evolution of land plants. Prokaryotes aside (but see Lyon 2015), the "recent" origins of subjective experience may well lie in "lower" animals and plants alike (Calvo 2017). It is the degree of phenotypic flexibility that can be observed in the behavioral repertoire of plants that supports the capacity for subjective experience in plants and licenses our quest for the origins of mind in plants. This remains an open empirical question, not unlike the question of the sentience of any other organic form (Baluška \& Mancuso 2009; Calvo 2017; Calvo, Sahi \& Trewavas 2017).

\footnotetext{
${ }^{3}$ For a working hypothesis about the non-neural substrate that would serve to implement it all in plants at the electrical level via long-distance signaling, see Calvo, Sahi \& Trewavas (2017). For a non-model-based alternative account of plant behavior, see Calvo, Raja \& Lee (2017).
} 


\section{References}

Acevedo, F. E., Rivera-Vega, L. J., Chung, S. H., Ray, S., \& Felton, G. W. (2015). Cues from chewing insects-the intersection of DAMPs, HAMPs, MAMPs and effectors. Current Opinion in Plant Biology, 26, 80-86.

Appel, H. M., \& Cocroft, R. B. (2014). Plants respond to leaf vibrations caused by insect herbivore chewing. Oecologia, 175, 1257-1266.

Baldwin, I. T., Halitschke, R., Paschold, A., von Dahl, C. C., \& Preston, C. A. (2006). Volatile signaling in plant-plant interactions: "Talking trees" in the genomics era. Science, 311(5762), 812-815.

Baluška, F. (2016). Should fish feel pain? A plant perspective. Animal Sentience 3(16).

Baluška, F., \& Mancuso, S. (2009). Plants and animals: Convergent evolution in action? In F. Baluška (Ed.), Plant-environment interactions: From sensory plant biology to active plant behavior (pp. 285-301). Berlin: Springer.

Baluška, F., \& Mancuso, S. (2013). Root apex transition zone as oscillatory zone. Frontiers in Plant Science, 4, art. 354.

Barron, A. B., \& Klein, C. (2016). What insects can tell us about the origins of consciousness. Proceedings of the National Academy of Sciences, 113(18), 4900-4908.

Bastien, R., Bohr, T., Moulia, B., \& Douady, S. (2013). Unifying model of shoot gravitropism reveals proprioception as a central feature of posture control in plants. Proceedings of the National Academy of Sciences, 110(2), 755-760.

Calvo, P. (2016). The philosophy of plant neurobiology: A manifesto. Synthese, 193, 1323-1343.

Calvo, P. (2017). What is it like to be a plant? Journal of Consciousness Studies, 24, 205-227.

Calvo, P. (book ms. in preparation). Plant cognition: The next revolution.

Calvo, P., \& Baluška, F. (2015). Conditions for minimal intelligence across eukaryota: A cognitive science perspective. Frontiers in Psychology, 6, 1329.

Calvo, P., \& Friston, K. J. (2017). Predicting green: Really radical (plant) predictive processing, Journal of The Royal Society Interface, 14, 20170096.

Calvo, P., \& Keijzer, F. (2011). Plants: Adaptive behavior, root brains and minimal cognition. Adaptive Behavior, 19, 155-171.

Calvo, P., Baluška, F., \& Sims, A. (2016). 'Feature detection' vs. 'predictive coding' models of plant behavior. Frontiers in Psychology, 7, 1505.

Calvo, P., Raja, V., \& Lee, D. N. (2017). Guidance of circumnutation of climbing bean stems: An ecological exploration. bioRxiv doi: 10.1101/122358.

Calvo, P, Sahi, V. P., \& Trewavas, A. (2017). Are plants sentient? Plant, Cell \& Environment, 40, 2858-2869.

Darwin, C. (1875). The movements and habits of climbing plants. London: John Murray.

Darwin, C. (1881). The formation of vegetable mould, through the action of worms with observations on their habits. London: John Murray.

Darwin C., \& Darwin, F. (1880). The power of movement in plants. London, UK: John Murray. Dennett, D. C. (2017). From bacteria to Bach and back: The evolution of minds. Norton.

Dicke, M., Agrawal, A. A., \& Bruin, J. (2003). Plants talk, but are they deaf? Trends in Plant Science, 8(9), 403-405. 
Dumais, J. (2013). Beyond the sine law of plant gravitropism. Proceedings of the National Academy of Sciences of the United States of America, 110(2), 391-392.

Falik, O., Reides, P., Gersani, M., \& Novoplansky, A. (2005). Root navigation by self inhibition. Plant, Cell \& Environment, 28, 562-569.

Franklin, K. A. (2008). Shade avoidance. New Phytologist, 179, 930-944.

Grüter, C., Wüst, M., Cipriano, A. P., \& Nascimento, F. S. (2018). Tandem recruitment and foraging in the ponerine ant Pachycondyla harpax (Fabricius). Neotropical Entomology, 1-8.

Hodge, A. (2009). Root decisions. Plant, Cell \& Environment, 32(6), 628-640.

Klein, C., \& Barron, A. B. (2016). Insects have the capacity for subjective experience. Animal Sentience 9(1).

Lyon, P. (2015). The cognitive cell: Bacterial behavior reconsidered. Frontiers of Microbiology, 6, 264.

Novoplansky, A. (2016). Future perception in plants. In M. Nadin (Ed.), Anticipation across disciplines (pp. 57-70). Springer.

Reber, A. S. (2016). Caterpillars, consciousness and the origins of mind. Animal Sentience 11(1).

Rhoades, D. F. (1985). Offensive-defensive interactions between herbivores and plants: Their relevance in herbivore population dynamics and ecological theory. The American Naturalist, 125, 205-238.

Shemesh, H., Arbiv, A., Gersani, M., Ovadia, O., \& Novoplansky, A. (2010). The effects of nutrient dynamics on root patch choice. Plos One, 5, e10824.

Trewavas, A. (2003). Aspects of plant intelligence. Annals of Botany, 92, 1-20.

Trewavas, A. (2014). Plant behaviour and intelligence. Oxford University Press.

Trewavas, A. (2017). The foundations of plant intelligence. Journal of The Royal Society Interface, 7, 20160098. 
UQÀM/ISC Cognitive Science Summer School June 26 - July 6 2018, Montreal, Canada

\section{The Other Minds Problem: Animal Sentience and Cognition}

Overview. Since Descartes, philosophers know there is no way to know for sure what - or whether - others feel (not even if they tell you). Science, however, is not about certainty but about probability and evidence. The 7.5 billion individual members of the human species can tell us what they are feeling. But there are 9 million other species on the planet ( 20 quintillion individuals), from elephants to jellyfish, with which humans share biological and cognitive ancestry, but not one other species can speak: Which of them can feel - and what do they feel? Their human spokespersons - the comparative psychologists, ethologists, evolutionists, and cognitive neurobiologists who are the world's leading experts in "mind-reading" other species -- will provide a sweeping panorama of what it feels like to be an elephant, ape, whale, cow, pig, dog, bat, chicken, fish, lizard, lobster, snail: This growing body of facts about nonhuman sentience has profound implications not only for our understanding of human cognition, but for our treatment of other sentient species.

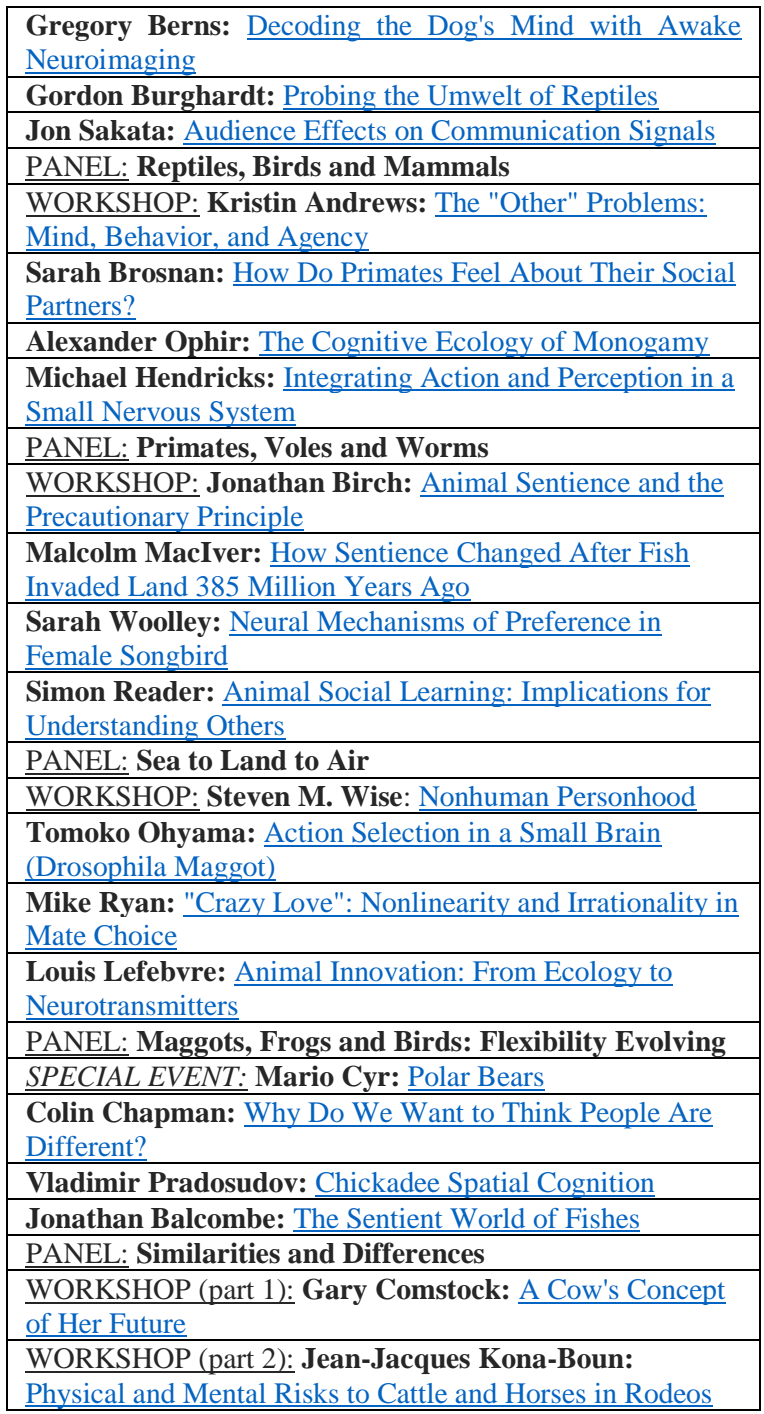

\begin{tabular}{|l|}
\hline Joshua Plotnik: Thoughtful Trunks: Application of \\
Elephant Cognition for Elephant Conservation \\
\hline Lori Marino: Who Are Dolphins? \\
\hline PANEL: Mammals All, Great and Small \\
\hline $\begin{array}{l}\text { Larry Young: } \text { The Neurobiology of Social Bonding, } \\
\text { Empathy and Social Loss in Monogamous Voles }\end{array}$ \\
\hline WORKSHOP: Lori Marino: The Inconvenient Truth \\
\hline About Thinking Chickens \\
\hline $\begin{array}{l}\text { Andrew Adamatzky: } \text { Slime Mould: Cognition Through } \\
\text { Computation }\end{array}$ \\
\hline $\begin{array}{l}\text { Frantisek Baluska \& Stefano Mancuso: What a Plant } \\
\text { Knows and Perceives }\end{array}$ \\
\hline $\begin{array}{l}\text { Arthur Reber: } \text { A Novel Theory of the Origin of Mind: } \\
\text { Conversations With a Caterpillar and a Bacterium }\end{array}$ \\
\hline PANEL: Microbes, Molds and Plants \\
\hline WORKSHOP: Suzanne Held \& Michael Mendl: Pig \\
Cognition and Why It Matters \\
\hline James Simmons: What Is It Like To Be A Bat? \\
\hline Debbie Kelly: Spatial Cognition in Food-Storing \\
\hline Steve Phelps: $\underline{\text { Social Cognition Across Species }}$ \\
\hline PANEL \\
\hline WORKSHOP: To be announced \\
\hline Lars Chittka: The Mind of the Bee \\
\hline $\begin{array}{l}\text { Reuven Dukas: } \text { Insect Emotions: Mechanisms and } \\
\text { Evolutionary Biology }\end{array}$ \\
\hline $\begin{array}{l}\text { Adam Shriver: } \text { Do Human Lesion Studies Tell Us the } \\
\text { Cortex is Required for Pain Experiences? }\end{array}$ \\
\hline PANEL \\
\hline WORKSHOP: Delcianna Winders: Nonhuman Animals \\
in Sport and Entertainment \\
\hline $\begin{array}{l}\text { Carel ten Cate: } \text { Avian Capacity for Categorization and } \\
\text { Abstraction }\end{array}$ \\
\hline Jennifer Mather: Do Squid Have a Sense of Self? \\
\hline $\begin{array}{l}\text { Steve Chang: } \text { Neurobiology of Monkeys Thinking About } \\
\text { Other Monkeys }\end{array}$ \\
\hline PANEL \\
\hline WORKSHOP: The Legal Status of Sentient Nonhuman \\
Species
\end{tabular}

